\title{
Etične dileme in izzivi humanizma v socialnem delu danes
}

\begin{abstract}
Socialno deloje prežeto zetičnimi dilemami. Te izhajajo tudi iz konflikta med humanističniminačeli in etičnimi imperativi socialnega dela ter trenutnimi usmeritvami v socialnih politikah in makroekonomskimi procesi. Različni elementi in dejavniki neoliberalne ureditve so s tega vidika relevantni tudi za razumevanje sodobne prakse socialnega dela, ki jo zaznamujejo deregulacija, deprofesionalizacija, privatizacija, uvajanje tržnih načel v storitve ipd. Socialno delo tako izgublja sposobnost za analizo in spreminjanje sistemskih, kolektivnih in individualnih razmer, ki nam organizirajo in določajo življenja. Koncept tveganja nadomešča koncept potreb, individualna krivda nadomesti imperativ solidarnosti. Kot kažejo tudi rezultati raziskave s socialnimi delavkami v Sloveniji in tuja literatura, se kljub demoralizirajočemustanjuv poklicu generiratudiupor. Socialno delo moraznova zavzeti svoje zagovorniško, kritično, radikalno stališče in ubraniti svoj mandat boja za človekove pravice in družbeno pravičnost.
\end{abstract}

Ključne besede:etika, neoliberalizem, tveganje, korporativizem, socialnadržava, kritičnomišljenje.

Dr. Ana M. Sobočan je docentka in raziskovalka na Fakulteti za socialno delo. Njeni osrednji raziskovalnitemista etika vsocialnem delu in etika vraziskovanju. Kontakt:ana.sobocan@fsd.uni-lj.si.

\section{Ethical dilemmas and challenges to humanism in contemporary social work}

Social work is permeated with ethical dilemmas. These also arise from the conflict between humanistic principles and the ethical imperatives of social work with current orientations in social policy and macroeconomic processes. From this point of view, various elements and factors of the neoliberal structure are also relevant for understanding modern social work practices characterized by deregulation, deprofessionalization, privatization, introduction of market principles into services, etc. In this way, social work loses its capacity to analyze and change the systemic, collective and individual conditions that organize and determine our lives. The notion of risk replaces the notion of needs, individual blame replaces the imperative of solidarity, and so on. As the results of research with social workers in Slovenia and foreign literature show, resistance to the demoralizing situation in the profession does exist. Social workneeds to resume its advocacy, critical, radical stance, and with the help of critical reflection and other methods defend its mandate for human rights and social justice.

Key words: ethics, neoliberalism, risk, corporativism, welfare state, critical thinking.

Ana M. Sobočan, PhD, is an assistant professor and researcher at the Faculty of Social Work, University or Ljubljana. Her main foci in research are ethics in social work and research ethics. Contact: ana.sobocan@fsd.uni-lj.si.

\section{Uvod}

Praksa socialnega dela je neločljivo povezana z vsakokratnimi politično-ekonomskimi usmeritvami in procesi pa tudi s posameznimi odločitvami, ki nastajajo v politično-ekonomskem prostoru in vplivajo na družbo (Garrett, 2009; 2013; Spolander, Engelbrecht in Pullen Sansfaçon, 2016). Čeprav ima socialno delo poklicne vrednote in tudi specifični epistemološki okvir, iz katerega se napajajo metode dela in pristopi, ter poklicno identiteto, ki oboje povezuje, ga zaznamujejo tudi zakonodaja, pravilniki, politične usmeritve ipd., ki so zato »zunanji« socialnemu delu, vendar ga sooblikujejo v aktualno prakso socialnega dela. 
Kot se strinjajo številni avtorji in avtorice s področja socialnega dela, ima velik vpliv na prakso socialnega dela (in izobraževanje za socialno delo) trenutni politično-ekonomski okvir (zahodnih) družb, tj. neoliberalizem (gl. npr. Ferguson in Lavalette, 2006; Wehbi in Turcotte, 2007; Rugowski, 2010; Wallace in Pease, 2011; Pemberton idr., 2016; Hyslop, 2018). V članku so predstavljeni nekateri elementi in dejavniki neoliberalne ureditve, prepoznani kot sklop vplivov na sodobno prakso socialnega dela. Vplivajo namreč na konflikt med humanističnimi načeli ter etičnimi imperativi socialnega dela in trenutnimi usmeritvami v socialnih politikah pa tudi na izbire in odločitve tistih, ki v socialnem delu delajo (socialne delavke in delavci) ali ga oblikujejo z vodstvenih položajev (direktorji centrov za socialno delo, vodje poklicnih organizacij, zaposleni na pristojnem ministrstvu, vladna telesa in ministri ipd.). V sklepnem delu članka so predstavljeni nekateri predlogi v zvezi z nujnim aktiviranjem socialnega dela proti učinkom neoliberalnih politik in za krepitev njegovih humanističnih vrednot in poklicne etike.

\section{Neoliberalizem in erozija socialnega}

Emancipacijski potencial socialnega dela danes je mogoče podpreti na relevanten način le, če razumemo »pravila igre [neoliberalizma] in njene globoke strukture « (Houston, 2012, str. 520). Avtorji s področja socialnega dela neoliberalizem označujejo kot enega temeljnih vplivov na sodobne socialne politike in prakso socialnega dela. Sam pojem neoliberalizem je težko opredeliti, saj je mogoče v literaturi najti zapise, ki ga označujejo na eni strani kot vsenavzočo silo, zeitgeist oz. duh časa (gl. Eagleton-Pierce, 2016), na drugi pa kot vsebinsko votel izraz, ki je namenjen predvsem ustvarjanju polemike, nima pa analitičnega dosega (gl. Springer, 2016). Definicije neoliberalizma, ki jih najdemo v literaturi, so različne, gotovo pa ga moramo razumeti kot politični in ekonomski projekt ter kot družbeni in kulturni fenomen; kot hibrid, ki izhaja iz kombinacije različnih dimenzij - ekonomske, politične, ideološke in sociokulturne. Razvija se že vse od dvajsetih let 20. stoletja. Nekateri avtorji sicer pišejo o koncu neoliberalizma, a v tem članku se strinjam z Garrettom (2018; 2019), ki piše o »retorično na novo umerjenem neoliberalizmu « (rhetorically recalibrated neoliberalism): o poskusih z diskurzom preobleči, zamaskirati neoliberalizem, s pomočjo komunikacijskih strategij, ki želijo zakriti kontinuirane in temeljne cilje neoliberalnega projekta. Garrett (2019) prepoznava dejavne povezave med abstraktnimi teoretizacijami neoliberalizma in tem, kar se dogaja na delovnih mestih, doma, v skupnostih - in seveda tudi v socialnem delu.

Na socialno delo neoliberalne ideje vplivajo gotovo že več kot štirideset let - ne nazadnje je v Čilu uvajanje neoliberalizma pomenilo tudi zapiranje šol za socialno delo, preganjanje, zapiranje in celo umore socialnih delavk in delavcev. $V$ sedemdesetih letih 20 . stoletja je neoliberalizem pridobil podpornike $\mathrm{v}$ političnih elitah velikih držav, od takrat naprej torej tudi zaznamuje sodobni globalni kapitalizem, katerega je od devetdesetih let tudi popolnoma prevzel s svojim avtoritarnim, restriktivnim in reakcionarnim etosom (Dale in Fabry, 2018). 
Najpogosteje ga razumemo kot teorijo ekonomsko-političnih praks, temelječo na prepričanju, da je za družbe najbolje, da liberalizirajo in deregulirajo vsakovrstne, s podjetništvom in storitvami povezane zakonodaje, institucionalni okvir naj zdaj sestavljajo prosti trg in trgovanje ter pravice v zvezi z zasebno lastnino (Spolander, Engelbrecht in Pullen Sansfaçon, 2016). Neoliberalizem zahteva umik države iz ekonomskega in storitvenega sektorja, z argumentom večjih ekonomskih učinkov (Harvey, 2010). Neoliberalne politike so se uveljavile hitro in nesporno, vladajoče elite so se nanje privadile in jih sprejele, s tem pa so jih sprejele tudi celotne družbe.

Od devetdesetih let je neoliberalni sistem izrazito opazen tudi v nekdanjih socialističnih državah in v Vzhodni Evropi, pozneje se je še krepil v državah Evropske unije pod vplivom Bruslja (Dale in Fabry, 2018). Po nekaterih analizah naj bi Slovenija v celotni svoji regiji najpočasneje doživela ekonomsko transformacijo (Becker, 2016) in imela »neokorporativistični« režim ali koordiniran model kapitalizma, znotraj katerega naj bi združevala uspešno delovanje na makroekonomski ravni, z demokratičnimi načeli in najugodnejšim sistemom države blaginje (Bohle in Greskovits, 2007a; 2007b; Adam, Kristan in Tomšič, 2008). ${ }^{1} \mathrm{O}$ tem, da je bil vpliv neoliberalnih idej še posebej značilen za socialo, zdravstvo, izobraževanje in podobno, v Sloveniji piše npr. Hedžet Tóth (2012). Ule in Kurdija (2013) v svoji raziskavi ugotavljata uveljavljanje neoliberalnih in liberalnih načel, kot so individualizacija skrbi za zdravje, izkoriščanje neplačanega dela žensk v domačem okolju, zmanjševanje in ukinjanje socialnih transferjev. Popović in Lukšič (2012) trdita, da se je v Sloveniji po osamosvojitvi uveljavil tržni sistem, pri tem pa je šlo za nekritično posnemanje Zahoda. Krašovec (2016, str. 75) opozarja, da gre v Sloveniji na vsakdanji ravni, tj. »na ravni seminarjev na zavodu za zaposlovanje, obravnave primerov na centrih za socialno delo, dnevne politike in mikrofizike upravljanja $\mathrm{v}$ javnih institucijah, nevladnih organizacijah, kulturnih zavodih in drugje, « za posebno obliko institucionalne in individualne etike, ki deluje na ravni mikroorganizacije delovnih, medosebnih in socialnih razmerij kot »oblika subjektivnih drž in metod odzivanja, ki nima vnaprej določene vsebine ali pravilnih stališč«.

Kljub polomu ekonomskega in družbenega razcveta, ki ga je neoliberalizem obljubljal in ga je dokončno negiral pojav svetovne gospodarske krize, ki se je začel pred več kot desetletjem, dediščina neoliberalnih politik in pojmovanj ostaja vplivna in opazna, tako $\mathrm{v}$ kolektivni miselnosti kot $\mathrm{v}$ javnih politikah. Ob tem se krepijo tudi desničarske populistično-avtoritarne sile, ki pomagajo izrinjati prejšnje socialno-demokratične ureditve. Neoliberalizem namreč ni le ekonomska doktrina, generira tudi javne diskurze ter vpliva na politične in družbene izbire in možnosti (Spolander, Engelbrecht in Pullen Sansfaçon, 2016).

1 Pri ocenah stanja v Sloveniji gre opozoriti, da temeljijo na analizah »zunanjih opazovalcev « in so bile narejene pred več kot desetletjem, zato situacije ne gre jemati tako optimistično, kot bom pokazala tudi v tem članku. Sicer pa so avtorji in avtorice v Sloveniji pozornost namenili npr. neoliberalizmu v šolstvu (gl. Sodobna pedagogika, letnik 59, št. 3). Naj opozorim tudi na Inuksuit - pet balad o neoliberalizmu za otroke Iztoka Osojnika (2013), ki je pomemben dokument časa v prostoru, kjer pravzaprav manjka analitičnega, celostnega kritičnega ovrednotenja sprejetja neoliberalnih idej v Sloveniji. 
A kako je mogoče, da smo družbe sprejele takšne spremembe? Kot je ugotavljal Milton Friedman ${ }^{2}$, ki je za način uvajanja novih politik uporabil izraz »šok terapija «, so hitrost, nenadnost in obseg ekonomskih sprememb sprožile psihološke reakcije, ki so olajšale prilagoditev na nove razmere (Dale in Fabry, 2018, str. 342). Foucaultova vladnost (governmentality) nam pomaga razumeti, da se neoliberalne reforme in prestrukturiranje družbe uveljavljajo s kompleksnim sistemom, ki pomeni vladanje ljudem in družbam ne le $\mathrm{z}$ »monopolom nad legitimnimi oblikami nasilja«, ampak tudi s pomočjo »prepričevanja « ljudi v nujnost tega vladanja in dominacije (Foucault, 2008). Vladnost prepriča ljudi, da sprejmejo legitimnost sistema kot nujnost - subjekti, ki se sistemu podredijo, so za to nagrajeni, tisti, ki se mu ne, pa kaznovani (Jönsson, 2019). Neoliberalna sporočila prepričujejo ljudi, da imajo nešteto možnosti, izbir in priložnosti ter da lahko vsakemu uspe, če se le dovolj potrudi. Posledica tega je, da so ljudje prepričani, da je karkoli mogoče, v resničnosti pa doživljajo razočaranja, marginalizacijo in viktimizacijo (Layton, 2010). V neoliberalni ureditvi je ključna individualizacija: posameznikom naj bi namreč uspelo zaradi lastnega trdega dela, naporov, spretnosti in znanja (po analogiji s tem, da naj bi v neoliberalizmu trg »naravno « nagrajeval uspeh in kaznoval poraz) (Cummins, 2018).

Tisti, ki ne dosegajo družbeno zaželenih ciljev, ki ne prispevajo k družbi v pomenu maksimalnih ekonomskih učinkov, so kaznovani, patologizirani in marginalizirani (Bay, 2018), v številnih državah pa že izključeni tudi iz minimalnih storitev ekonomskega in družbenega varstva (Reisch, 2013; Webb 2006). Socialne politike so izraz širših družbenih in kulturnih pogledov in prepričanj: $v$ javnem, političnem in medijskem diskurzu so za prazno javno blagajno odgovorni prejemniki socialne pomoči (Cummins, 2018). Ti so zdaj pogosto označeni kot »fehtarji« ali »izkoriščevalci« (Grover in Piggott, 2005), kvazievgenična ideologija pa prelaga odgovornost za socialno prikrajšanost na "problematične družine« (Fronek in Chester, 2016). S takšno podlago se med neoliberalno ureditvijo in državo blaginje vzpostavlja poseben odnos: recesija, v imenu katere se krčijo pravice (ki se financirajo iz državnega proračuna), je le podaljšek neoliberalne agende, ki sprejemanje finančnih in drugih pomoči predstavlja kot moralni problem, saj naj bi ustvarjalo odvisnost in zmanjševalo samostojnost in samozadostnost vsakega posameznika (Leskošek, 2014; Cummins, 2015). Zmanjševanje pravic in storitev spremlja tudi ambivalenca strokovnih delavk in delavcev do uporabnikov storitev, ki postanejo "potrošniki« storitev, pogosto pa je - kot naznanjajo populistični politični diskurz in mediji - osrednje sporočilo: državne podpore ustvarjajo odvisnost, so previsoke, vsi, ki jih koristijo, varajo sistem in vsega tega si preprosto ne moremo več privoščiti, saj v blagajno plačujejo le tisti, ki »trdo in pošteno delajo« (Leskošek, 2017; Stark, 2011). Revščina npr. tako postane osebni problem in lastna odgovornost in je zdaj nepovezana s političnim, kulturnimi in drugimi dejavniki; vprašanje revščine tudi ni več povezano z vprašanji kolektivne odgovornosti in solidarnosti.

2 Milton Friedman je bil eden od ustanoviteljev društva Mont Pelerin in ena od osrednjih osebnosti Čikaške šole za ekonomijo in tako eden od osrednjih akterjev pri oblikovanju neoliberalnih idej. 


\section{Vpliv neoliberalnih pristopov na socialno delo}

Socialne politike in dejansko prakso v socialnem delu in socialnovarstvenih poklicih sooblikujejo različni vplivi, težnje in vrednote - a med njimi so pomembna tudi neoliberalna načela, kot sem jih opisala. Posledice neoliberalnih ekonomsko-političnih procesov za socialno delo oz. na krizo v socialnem delu (Ornellas idr. 2018) so dobro dokumentirane v mednarodni znanstveni literaturi, še posebej v zvezi s problemi in erozijo socialnodelovne poklicne identitete in etične prakse (Pullen Sansfaçon, 2011), erozijo poklicnih meja in deprofesionalizacijo (Asquith, Clark in Waterhouse, 2005), rekrutacijo in zadržanjem strokovnih delavk in delavcev (Spolander idr., 2010), poklicnimi pritiski in izgorevanjem (Evans idr. 2006), (ne)zadovoljstvom v službi ipd. (Lymbery, 2001).

Skupne lastnosti posledic neoliberalne ureditve tako lahko identificiramo na področju socialnih politik in prakse socialnega dela kot vse večjo marginalizacijo uporabnikov storitev, zmanjševaje storitev s področja preventive ter povečanje nadzora in upravljanja strokovnih delavk in delavcev (npr. Reisch, 2013; Rogowski, 2012). V praktičnem pomenu so delovne razmere zaznamovane z zmanjšanjem zaposlenih in večanjem delovnih obveznosti; s povečano obveznostjo evidentiranja in torej pisarniškega dela; s preusmerjanjem ljudi na iskanje pomoči v neformalnih mrežah in dobrodelnih organizacijah; in s prepoznavanjem elementov realnosti, ki so skupni socialnim delavkam in uporabnikom. Poklicna vloga socialnega dela se fragmentira, se pravi, da se procesi v praksi drobijo na manjše dele, to pa omogoča večji nadzor in zmanjševanje strokovne diskrecije pa tudi uvajanje delitev dela med socialne delavke in druge (tudi cenejše, manj kvalificirane poklice).

Podobno velja tudi za Slovenijo: Vesna Leskošek (2011) v analizi novejše in nove slovenske zakonodaje $\mathrm{v}$ zvezi s socialnim varstvom opozori na značilnosti, kot so deregulacija, deprofesionalizacija, privatizacija socialnega varstva in uvajanje trga. Za izvajanje socialnovarstvenih storitev strokovna izobrazba ni več relevantna; zakonodaja omogoča podjetizacijo, privatizacijo in novo upravljavsko miselnost, po kateri naj bi se socialno varstvo približalo funkcioniranju gospodarstva, z zavajajočimi in lepo zvenečimi pojmi, kot so modernizacija, posodabljanje, izbira, fleksibilnost. S takšnimi spremembami se seveda temeljito spreminja koncept socialne države, kot smo ga poznali do zdaj (Leskošek, 2011; 2017).

Socialno delo pod vplivom neoliberalizma postaja vse šibkejše z več vidikov: kadrovsko, strokovno, epistemološko. Socialno delo kot poklic v teh okoliščinah izgublja dolgotrajno temporalno referenco, ki je pogoj za sistematično transformacijo življenjskih potekov pa tudi sistemov socialnih politik. Socialno delo izgublja tudi nadindividualni pogled, ki omogoča kompleksno in sistematično razumevanje socialnih problemov in njihovih vzrokov. Izgublja temelj za argumentacije, povezane s socialnimi pravicami in pravičnostjo $\mathrm{v}$ odločitvah in se reducira na upravičenost in ekonomsko učinkovitost storitev. Koncept »stalnosti« v neoliberalnem sistemu prevlada nad konceptom družbene spremembe; koncepta učinkovitosti in merljivih rezultatov (ki so funkcionalni in takojšnji) postaneta pomembnejša od procesa, koncept individualne odgovornosti pa izrine kolektivno solidarnost. 
V skladu z neoliberalnim premikom k osebni odgovornosti in krivdi se tudi vse več socialnega dela osredotoča na to, kako se bosta sama spremenila posameznica in posameznik, vse manj govora pa je o tem, kako je treba spreminjati institucije, politike in družbeno ureditev. Socialno delo je na lepem ločeno od identificiranja strukturnih in institucionalnih vidikov socialnih problemov in odzivanja nanje, saj naj bi bili uporabniki in uporabnice sami odgovorni za svoje stanje. Odmik od skupnostnega dela pomeni tudi okrnjeno mobilizacijo skupnosti in kolektivnih akcij (Gill, 2012). Socialne delavke in delavci so torej predvsem street level bureaucrats (Lipsky, 1980), tj. javni uslužbenci, birokrati, ki izvajajo državne politike, niso pa katalizatorji družbenih sprememb, čeprav jim sicer to nalaga njihova poklicna identiteta (Garrett, 2014; Noordegraaf, 2016).

Neoliberalne politike hkrati erodirajo javno podobo o učinkovitosti socialnovarstvenih storitev in priskrbijo ideološke podlage za sistematično demontažo države blaginje (Kus, 2006). Ta sporočila vplivajo na ustvarjanje strahu pred neučinkovitostjo delovanja institucij, ki onemogoča zaupanje v njihovo učinkovito (in tudi pravično) delovanje. Kot ugotavljajo Florin in drugi (2018) za romunske socialne delavke, ta sporočila pripomorejo tudi $\mathrm{k}$ občutkom samorazvrednotenja socialnih delavk (ne le javnega in političnega razvrednotenja njihove vloge). Strah, celo prepričanje glede neučinkovitosti pri javnosti in posebej pri uporabnikih in uporabnicah vpliva na to, da se tudi pri socialnih delavkah ustvarjajo občutki negotovosti, strahu pred neuspešnostjo in lastnim dvomom o sebi (Bay, 2018). S strahom pa je neločljivo povezan tudi fenomen tveganja, ki je prav tako eden osrednjih pojmov, ki se pojavljajo v zvezi z neoliberalizmom.

Koncept tveganja zelo vpliva tudi na usmeritve v praksi socialnega dela, ki naj bi bila vse bolj defenzivna, preveč proceduralizirana in osrediščena na merjenje tveganj in upravljanje z njimi. Tvegaje je pomemben diskurzivni konstrukt, ki oblikuje socialnodelovno znanje, prakso in etiko. Številni avtorji trdijo, da je usmerjenost socialnih politik in socialnega dela $v$ današnjem času določa tveganje (risk-led), ne pa potrebe (needs-led) (Kemshall, 2002; Parton in O'Bryne, 2000; Green, 2007). Socialno delo naj bi zato konstruiralo uporabnike kot objekte tveganj, ki jih je treba preučevati, meriti in popravljati; kot objekt tveganja je tako uporabnik izpostavljen zaporedju disciplinirajočih praks, ki so namenjene preobrazbi in nadzoru (Stanford, 2010). V raziskavi, ki je sicer potekala v Avstraliji, je avtorica Stanford (2010) odkrila, da socialne delavke govorijo o tveganju kot o osebni lastnosti, tveganje je torej personalizirano in se napaja iz občutkov strahu. Ugotavljala je, da so socialne delavke tveganje razumele kot realnost in nenehno navzočo silo v svoji praksi; tveganje so doživljale kot osebno, ne kot sistemsko vprašanje; tveganje so dojemale kot izključno negativno in grožnjo; tveganje je bilo predstavljeno kot moralno vprašanje svoje identitete in identitete uporabnikov in uporabnic so v zvezi s tveganjem pozicionirale $\mathrm{v}$ skladu $\mathrm{z}$ moralno primernostjo in neprimernostjo. Tudi pri odločanju v praksi, tj. pri etičnih dilemah in konfliktih, je po Stanford tveganje ključno: socialne delavke v njeni raziskavi so nekatere uporabnike doživljale kot izpostavljene tveganju ( $\mathrm{tj}$. ranljive tako v kontekstu svojega življenja kot 
tudi v procesu pomoči, ki utegne biti preveč nadzorujoč, restriktiven, paternalističen) in hkrati kot tveganje (osebe so nevarne sebi in socialni delavki); pri tem so pogosto tudi sebe videle v eni od teh dveh vlog (so v nevarnosti - zaradi uporabnika pa tudi očitkov družbe - ali so same nevarnost za uporabnike, bojijo se, da jim ne bodo mogle pomagati). Vprašanje je: čemu bodo socialne delavke dale prednost, za koga bodo poskušale zmanjševati tveganje?

Navedeni sklop mehanizmov - tudi vsiljevanje načel trga, zmanjševanje finančnih sredstev, ki so na voljo za sam poklic in za potrebe uporabnikov socialnega dela, in neoliberalni diskurzi in populistične krilatice o tem, da nas država blaginje preveč stane in da uporabniki izkoriščajo državo - se združuje v skupnem cilju iztiriti etično prakso, demoralizirati in prestrašiti socialne delavke in delavce $v$ praksi, razrahljati temelje socialnega dela in preobraziti odnos in poglede na to, kaj pomeni država blaginje. Cree (2013) se sprašuje, kako naj socialne delavke povečajo moč drugim, če pa kot uslužbenke v državnih institucijah nimajo nadzora niti nad lastnim poklicnim življenjem in identiteto? V kontekstu strukturnih okoliščin, ki določajo in omejujejo avtonomijo posameznice, je - kakšen paradoks - ključno prav to, kakšen bo odziv posameznice, socialne delavke, saj mora prav ona vsak dan sprejeti izbire, ki potrjujejo ali nasprotujejo prevladujočim usmeritvam.

\section{Etične dileme in kriza socialnega dela}

Etične dileme so stalnica v praksi socialnega dela, velikokrat preprosto zato, ker potrebe uporabnikov in uporabnic presegajo vire, ki jih ima na voljo socialno delo (Lymbery, 2001). Z neoliberalnimi idejami zaznamovane usmeritve, navodila, diskurzi v praksi socialnega dela vplivajo na generiranje etičnih dilem. Socialne delavke in delavci - ne pa npr. tudi vodje, odločevalci, politiki (tisti torej, ki navedene vire dodeljujejo socialnemu delu) - morajo doživljati razočaranja uporabnikov in uporabnic, poslušati morebitne očitke javnosti glede pomanjkanja virov in pravil glede tega, kdo in s kakšnimi pogoji je upravičen do finančne in drugih pomoči. Zato se pogosto počutijo nemočne in nezmožne pomagati ter vse bolj odtujene od svoje poklicne vloge (Pullen Sansfaçon, 2011; Sobočan, 2013).

$S$ pojmom etična dilema mislim na izbire med dvema enako neustreznima možnostma, ki jo pogosto določa tudi konflikt moralnih vrednot. Vsekakor niso vse dileme, s katerimi se srečujejo socialne delavke, tudi etične, je pa socialno delo vsekakor prežeto z njimi (Sobočan, 2013), tudi zato, ker so lahko vprašanja, ki so za nekoga praktična ali tehnična, za drugega etični problemi (Banks, 2006). ${ }^{3}$ Skoraj praviloma izidi etičnih dilem niso samo pozitivni ali

3 Primer: delo zaposlenih na centrih za socialno delo določa Katalog javnih pooblastil, nalog po zakonu in storitev, ki jih izvajajo CSD, ki tudi opredeljuje, koliko časa lahko socialna delavka največ nameni posamezni storitvi oz. opravilu ali aktu. Če določeno opravilo obsega dve srečanji z otrokom, socialna delavka nima podlage $v$ dokumentnem sistemu in načrtovanju svojega delovnika, da opravi več srečanj, kadar s strokovnega vidika v posameznem primeru ocenjuje, da dve srečanji ne bosta dovolj. Za nekatere socialne delavke je praktično vprašanje, kako se omejiti na dve srečanji, za nekatere je etično vprašanje, ali in kako opraviti več srečanj, če obstaja strokovna ocena, da dve srečanji ne bosta dovolj. 
preprosti, tako kot to niso niti razlogi za dilemo. Vendar ima veliko vlogo pri tem, kako etična je odločitev in kako jo bodo sprejeli deležniki, proces odločanja (Sobočan, 2012). Odločanje, ki ga lahko označimo kot etično, je proces, ki je premišljen od zunaj in od znotraj : a) je sistematičen, to je temeljit, motiviran, odgovoren, strokovno kompetenten in z znanjem podprt pristop, ki vključuje sposobnost za prepoznavanje in odzivanje na etične dimenzije prakse in delovnega okolja ter za ravnanja z njimi (med/osebni, inter/kolegialni, strukturni in družbeni vidiki); b) je samorefleksiven, se pravi, da vključuje poznavanje sebe (svojih vrednot, preferenc in prepričanj ter v kakšnem odnosu so te z strokovnimi vrednotami); kot tudi vedênje, kakšne etične perspektive posameznica po navadi ima (tj. pristope etike skrbi, teleološke, deontološke, pragmatične ipd.) in sposobnost za prepoznavanje in evalvacijo lastnih moralnih sodb in za ravnanje z njimi (glede vedenja ljudi, situacij, dejstev ipd.).

V raziskavi, ki je že pred skoraj desetletjem in znova pred nekaj leti preučevala, kako z etičnimi dilemami ravnajo socialne delavke in delavci v Sloveniji, so pričevanja socialnih delavk pokazala: da v praksi skoraj ni več časa za pripravo, premislek, posvetovanje; tudi avtonomija in diskrecija $\mathrm{v}$ praksi sta za socialne delavke vse bolj omejeni; odločanje v praksi je polno hitrih in tehničnih odločitev za kratkoročne intervencije (Sobočan 2013; 2017; 2018). Podobno ugotavljajo tudi avtorji iz drugih evropskih držav, ki so raziskovali socialno delo v času neoliberalizma in še posebej v času varčevalnih ukrepov po svetovni gospodarski krizi 2007-2008 (t. i. austerity) (Garret in Bertotti, 2017; Ioakamidis, Santos in Herrero, 2014; Jordan in Drakeford, 2012; Karakgounis, 2017; Florin idr. 2018). V tem času so z vidika socialne politike najučinkovitejše in najbolj izvedljive rešitve določali predvsem strogo gospodarjenje in stroški - veliko manj pa strokovna presoja. Nadzor in vodenje prakse socialnega dela s cilji ekonomske učinkovitosti (npr. z omejevanjem zaposlovanja strokovnih delavk, ukinjanjem programov in storitev, avtomatizacijo določenih storitev, npr. dodeljevanja denarne socialne pomoči, z zviševanje normativov dela, nedostopnostjo supervizije in izobraževanj za socialne delavke, novimi orodji in pristopi za nadzor ljudi) (Gray idr., 2015) pomenita nevarnost, da se bodo socialne delavke $v$ praksi pogosteje odločale predvsem tako, da bo njihovo delo finančno vzdržno v skladu z novimi standardi, npr. ne informirajo o vseh pravicah, ne ponudijo določenih storitev, izvajajo večji in natančnejši nadzor nad uporabniki (Sobočan, 2013). Konflikt med pomočjo ali sodelovalnimi odnosi in nadzorom ali disciplinirajočimi odnosi ustvarja stisko in notranja nasprotja v praksi socialnega dela; gre za etični konflikt, ki je podstat vsega ravnanja v praksi, konflikt, s katerim se socialne delavke in delavci srečujejo nenehno.

Pomembno pri tem pa je, da socialno delo vsekakor ni le žrtev neoliberalizma (Spolander, Engelbrecht in Pullen Sansfaçon, 2016). Tudi socialno delo se je neoliberalnim idejam sorazmerno hitro prilagodilo (Jordan, 2005) in številne organizacije ter socialne delavke in delavci brez spraševanja upoštevajo usmeritve in socialnopolitične odločitve, ki jih oblikujejo vlade ali drugi odločevalci. Raziskovalci ugotavljajo, da so se nekatere socialne delavke in delavci, ker so se hoteli umakniti pred strukturnimi spremembami, zatekli v terapevtsko ali klinično socialno delo (Wallace in Pease, 2011). Morda še 
vedno lahko trdimo, kot je že petnajst let nazaj ugotavljal Lorenz (2005), da socialno delo ni razvilo kritičnosti do lastne vloge $\mathrm{v}$ spremembah, ki jih vpeljujejo neoliberalne ideje. Socialne delavke in delavci v praksi bi se morali odločati in odločiti, ali bodo ravnali v vsem tako, kot jim je bilo naročeno oz. v skladu z navodili, ki jih imajo, pa čeprav bi bila ta v neskladju z vrednotami poklica in načeli človekovih pravic; ali pa bodo iskali, kako skupaj z uporabniki in uporabnicami, pogosto v vse hujših okoliščinah, preprečevati nadzorovalen, disciplinirajoč in poniževalen odnos do ljudi.

\section{Humanizem in etika v socialnem delu}

Socialno delo, pri katerem prakso vodijo načela človekovih pravic, humanizma, demokratičnosti in prepoznavanje človečnosti in negovanje človeškega dostojanstva, vsekakor je mogoče. ${ }^{4}$ A kako izvajati etično, humanistično socialno delo? Kot je namreč ugotavljal Ife (2002) že pred dvema desetletjema, institucije, v katerih delajo socialne delavke, ne zagovarjajo etičnih vizij poslanstva socialnega dela. $V$ socialnem delu po vsem svetu so posamezniki in posameznice pa tudi kolektivi in skupine, ki zavestno ravnajo v nasprotju z navodili, ki jih prepoznavajo kot neskladna s stroko in etiko socialnega dela. Takšna ravnanja opravičujejo s pomočjo vrednot socialnega dela - da namreč to počnejo zato, da bi v zaostrenih političnih in finančnih okoliščinah svojim uporabnikom sploh lahko še zagotovili človeka dostojno pomoč.

$\mathrm{V}$ raziskavi s socialnimi delavkami v Sloveniji, ki je bila izvedena $\mathrm{v}$ letih 2016/2017, so skoraj vse od 27 socialnih delavk, ki so odgovarjale na vprašanja $\mathrm{v}$ daljših narativnih intervjujih, navedle vsaj en primer, ko so same in še pogosteje skupaj s sodelavkami iskale in tudi našle način, kako zagotoviti potrebno pomoč in uresničiti strokovne vrednote kljub omejujočemu zakonodajnemu okviru ali različnim birokratskim in sistemskim oviram (Sobočan, 2017; 2018). Ravnanja so vključevala npr.: vzpostavljanje novih storitev, ki še niso obstajale oz. za katere v zakonodajnem okviru ni bilo možnosti; iskanje načinov za pridobitev denarne-socialne pomoči, kadar so ugotavljale, da jo oseba nujno potrebuje, čeprav do nje ni upravičena; vse do situacij, ki s samim socialnim delom niso povezane, a so socialne delavke prepoznale, da je treba zagotoviti osnovne razmere, da bi oseba lahko bila upravičena do pravic (takšen je bil primer osebe brez slovenskega državljanstva in celo brez dokumentov že vse od rojstva: manjša skupina socialnih delavk je potovala v tujino, da bi pomagale pridobiti osebni dokument, ki je v našem sistemu dodeljevanja pravic nujen).

Takšnih odzivov in ravnanj je v vsakodnevni strokovni praksi gotovo veliko ${ }^{5}$ (gl. npr. Gray in Webb, 2013), problematično pa je, da morajo za ohranjanje

4 Leta 2020 so poseben izziv za prakso socialnega dela pomenili tudi pandemija covida-19 in spremljajoči ukrepi, ki so vključevali tudi zapiranje socialnovarstvenih storitev in zavodov, krčenje finančne pomoči, delo brez osebnega stika ipd. Kot ugotavljajo raziskovalke in raziskovalci v raziskavi o etičnih izzivih v času pandemije (Banks idr., 2020), je etika v socialnem delu možna in še posebej nujna tudi v tako zaostrenih časih.

5 V letu 2020 je bila ena osrednjih dilem v praksi, kot kaže raziskava Banks idr. (2020), ali pri ravnanju v praksi upoštevati navodila nadrejenih in oblasti ali pa vrednote socialnega dela in strokovno znanje. 
strokovnosti in etičnega odnosa socialne delavke in delavci tako pogosto delovati v neskladju s pravili in navodili: in tako sebe, pogosto pa tudi uporabnike in uporabnice izpostavljati možnim posledicam in ranljivosti. Gre namreč za dejanja upora. White (2009) je tako identificirala dva temeljna odziva v praksi socialnega dela na neoliberalno paradigmo: poimenovala ju je upor z odmikom (resistance through distance) in upor z vztrajanjem (resistance through persistence). Pojem »upor z odmikom « opisuje načine, s katerimi socialne delavke ustvarjajo ustvarjalne prostore svoje prakse, ki presegajo kaznovalne in omejujoče predpise in pravila, pojem »upor z vztrajanjem « pa opisuje načine, na katere socialne delavke uporabijo svoje znanje, da posredujejo pri odločanju in ravnajo kot zagovornice svojih uporabnikov. White tudi kategorizira ravnanja, s katerimi se socialne delavke upirajo politikam, ki so v konfliktu z vrednotami socialnega dela, in obsegajo: prilagajanje presoj oz. strateško manipulacijo podatkov o uporabnikih; izogibanje postopkom in hierarhijam odločanja s pomočjo zavlačevanja ali premeščanja (npr. celotna potrebna dokumentacija je pripravljena šele, ko vodilnih ni več v službi, odločiti pa se je treba takoj); intenzivnejše sodelovanje z nadrejenimi v primeru tistih nalog, ki se izvajajo po predpisanem poteku (s tem pri vodilnih vzpostavijo zaupanje v legitimnost svojih praks); ignoriranje navodil nadrejenih; cinizem (komentiranje praks in politik); umik iz aktivne participacije na delovnem mestu (pogosto odhajanje na bolniški stalež ali celo menjava službe) (White 2009).

Zgolj identifikacijo in analizo praks upora pa presega Banks (2016), ki je razvila koncept »etičnega dela« (ethics work). Pojem opisuje dnevna, včasih celo urna prizadevanja za ohranjanje etičnega pristopa in spoprijemanje z etičnimi dilemami in konflikti v strokovni praksi. Poudarek na besedi »delo« kaže, da je vpeljevanje in vzdrževanje etične prakse samo na sebi delo, ki zahteva napor, predanost in zavestno odločitev (ibid.). Nenehno etično delovanje je razdelila na več kategorij, ki so vse moralno zaznamovane in prežete z etično dimenzijo v praksi in obsegajo: identifikacijo etično relevantnih vidikov situacije (kaj se v določenem primeru dogaja, še posebej v zvezi s pravicami, odgovornostmi in posledicami), pozicioniranje v svoji strokovni vlogi (katero vlogo prevzeti $\mathrm{v}$ določeni situaciji z določenimi ljudmi in kako se gibati med različnimi vlogami), čustveno delo (skrbnost, sočutje; ravnanje s čustvi, krepitev zaupanja; odzivanje na čustva drugih); ukvarjanje z identiteto (kako z interakcijo, odnosom in ravnanjem posredujemo drugim informacijo, kakšna je naša strokovna in tudi osebna identiteta), premišljevanje in preudarjanje (odločanje o tem, katero ravnanje in odločitve so etično sprejemljivi in ustrezni), ukvarjanje z odnosi (kako vzpostavljamo dialog z drugimi; ukvarjanje z odnosi s pomočjo čustev, identitete in premišljenih ravnanj) in predstavljanje vidikov lastnega dela drugim (Banks, 2016).

Teoretizacija Sarah Banks kaže, kako razvejeni in kompleksni so elementi vsakodnevne prakse socialnega dela in kako je mogoče tudi z zavestnim in premišljenim vzpostavljanjem etičnih praks na vsakodnevni ravni, tudi kadar naše prakse ne vključujejo nenehnega upora ali postavljanja po robu trenutnim socialnim politikam, zagotoviti, da socialno delo ni le v službi dominantnih neoliberalnih diskurzov, ampak upošteva vrednote socialnega dela. 
White (2009) in Banks (2016) pokažeta, kako se upirati praksam, ki niso v skladu z vrednotami, zapisanimi v kodeksih etike in globalni definiciji socialnega dela, in kako vzpostavljati in vzdrževati etični odnos, Hyslop (2018) pa celo ugotavlja, da bi se socialno delo lahko otreslo in bi se moralo otresti neoliberalizma, na temeljih svoje identitete poklica. Ker je socialno delo v vmesnem prostoru med potrebami uporabnikov in zahtevami sistema, je, kot meni Hyslop (2018), v zadnjih desetletjih razvilo nove spretnosti in znanja (npr. na področju reprezentacij, ravnanja z negotovostjo, obvladovanja ambivalentnosti in konflikta ter delovanja $v$ dveh različnih svetovih hkrati), ki naj bi pripomogli k preseganju omejitev, ki jih vzpostavljajo neoliberalni diskurzi in politike.

\section{Kako naprej?}

Socialne delavke in delavci se zavedajo, da morajo človekove pravice sobivati s kolektivno odgovornostjo, saj razumejo, da je posamezne človekove pravice mogoče v vsakodnevnem življenju uresničevati le, če ljudje prevzamejo odgovornost drug za drugega in za okolje in če si prizadevajo za ustvarjanje vzajemnih odnosov v skupnostih. (Globalna izjava o etičnih načelih v socialnem delu, 2018, člen 2.4.)

Globalna izjava o etičnih načelih v socialnem delu (2018; slovenski prevod 2019) nas opozarja na kolektivno (in individualno) odgovornost v socialnem delu (na lokalni in globalni ravni) za udejanjanje človekovih pravic. Morda bi bilo te lažje uresničevati, če se socialnemu delu ne bi bilo treba ukvarjati s samoohranitvijo in reševanjem konflikta med upoštevanjem strokovnih vrednot in odporom navodilom, ki jih oblikujejo politični odločevalci. Morda bi se tako socialne delavke in delavci lažje osredinili na soustvarjanje enakopravnejše in pravičnejše družbe za vse njene članice in člane, skupaj z uporabniki in na podlagi znanja in izkušenj.

Tudi v Sloveniji se zdaj srečujemo z velikimi izzivi legitimnosti, avtoriteti in mandatu socialnega dela, ki se očitno zanemarjajo, devalvirajo in demontirajo na več različnih področjih, kot so procesi reorganizacije, urejanje dolgotrajne oskrbe, zaščita otrok. Vse to so področja, kjer so v zadnjih letih raziskovalke in raziskovalci v socialnem delu, pogosto skupaj z uporabniki in uporabnicami ter ljudmi, ki delajo v praksi socialnega dela, dobro raziskali potrebe in ugotavljali smiselne rešitve, a niso bile implementirane (nekatere raziskovalke Fakultete za socialno delo, osebna komunikacija, 10.-15. 8. 2019). Izguba znanstvene, teoretske dimenzije je tesno povezana z depolitizacijo pa tudi z izgubo profesionalne identitete: novejša študija na Švedskem npr. ugotavlja, da imajo sodobni poudarki »modernizacije« in »profesionalizacije« v socialnem delu na Švedskem za cilj nadomeščanje kritične analize in perspektive za razumevanje in delo s socialnimi problemi (Jönsson, 2019).

Kot trdita Morley in Mcfarlane (2014, str. 336), je kritična refleksija lahko način upora neoliberalizmu, skupaj s kritičnimi in radikalnimi praksami, ki so blizu načelom enakosti, demokracije, družbene pravičnosti, človekovimi 
pravicami. Pri tem je pomembno tudi izobraževanje za socialno delo, ki naj pripomore h kritičnemu, poglobljenemu in trajnostnemu znanju. Če imajo namreč socialne delavke in delavci dobro znanje o socialnem delu (še posebej če razumejo življenjski potek uporabnikov, socialno pravičnost in zatiranje, vrednote socialnega dela in pomen teh $\mathrm{v}$ praksi), lahko iz tega ustvarjajo strokovno in s tem tudi etično prakso. Če sta takšni razumevanje in znanje šibki, vsakodnevno prakso brez težav preplavijo organizacijska, proceduralna in menedžerska znanja, ki nadomestijo znanje socialnega dela. $S$ tem se veča verjetnost, da bo etična podlaga socialnega dela erodirala in bodo socialne delavke in delavci le še procesirale in upravljale ljudi, s katerimi delajo. Morley in Macfarlane (2014, str. 352) sta pokazali, da se študenti in študentke, ki pridobijo spretnost kritičnega mišljenja, verjetneje poglobijo in razmislijo o idejah in teorijah, ki so jim izpostavljeni, in jih ne sprejemajo nekritično in nekontekstualizirano (znajo jih umestiti v življenjske situacije); problematizirajo ponotranjanje dominantnih diskurzov in ideologij; opozarjajo na domnevno nevtralnost »dejstev « ali mnenj in razmišljajo o kontekstih, razlogih in alternativnih scenarijih; ustvarjajo prostor za diskrecijo, v katerem lahko delujejo za etične in pravične izide za uporabnike kljub kontekstom, ki so lahko sovražni do kritičnih in emancipacijskih ciljev.

Če se vrnem k odgovornosti socialnih delavk in delavcev: ta je v tem, da - s pomočjo znanosti socialnega dela (teoretskih temeljev) in vpogleda v realnost življenj ljudi na robu v praksi - identificirajo, kje in kako se odmikamo od idealov demokratičnosti, humanizma, človekovih pravic in socialne pravičnosti. Socialne delavke in delavci se morajo prepoznati kot akterji, ki lahko delujejo in morajo delovati kolektivno, da bi rekonstruirali zaupanje v svoj poklic in moč znanja ter se povezali v družbena gibanja odpora. Socialne delavke in delavci lahko povedo in morajo povedati, da jim ni vseeno, sporočati, kako in kje se kršijo pravice in dostojanstvo ljudi, in dejavno zahtevati spremembe in se v zvezi s tem mobilizirati. Socialno delo, ki izhaja iz svojih temeljnih vrednot, lahko najde in mora najti svoj glas in samozavest, da zagovarja pomen univerzalnega dostopa do storitev, zahteva transparentno sprejemanje socialnih politik z vključevanjem stroke in uporabniških skupin in promovira idejo, da je delovanje v skladu s socialno pravičnostjo ključno za družbo in vse njene člane in članice (Spolander, Engelbrecht in Pullen Sansfaçon, 2016). Ne nazadnje Kodeks etike socialnih delavk in delavcev Slovenije (2021) v uvodnih določilih sporoča, da je "poslanstvo socialnih delavk in socialnih delavcev zagovarjanje družbene blaginje, spoštovanje človekovih pravic, solidarnosti, enakopravnosti in trajnosti« ter da z znanjem in spretnostmi, ki jih socialne delavke imajo, razvijajo samopomoč in samoorganizacijo ljudi, uporabnikov in uporabnic, izboljšujejo dostopnost do obstoječih in novih virov pomoči in vplivajo na zakonsko regulacijo socialnih pravic ter na prilagajanje in razvoj socialne politike. 


\section{Viri}

Adam, F., Kristan, P., \& Tomšič, M. (2013). Između neoliberalizma i neokorporativizma: Estonija i Slovenija u komparativnoj perspektivi. Revija za socijalnu politiku, 15(2), 135-150.

Asquith, S., Clark, C., \& Waterhouse, L. (2005). The role of the social worker in the 21st century: a literature review. Edinburgh: Scottish Executive Education Department.

Banks, S. (2006). Ethics and values in social work. Houndmills: Palgrave Macmillan.

Banks, S. (2016). Everyday ethics in professional life: social work as ethics work. Ethics and Social Welfare, 10(1), 35-52.

Banks, S., Cai, T., de Jonge, E., Shears, J., Shum, H. Y. M., Sobočan, A. M., Strom-Gottfried, K., Truell, R., Perman, M. J. U., \& Weinberg, M. (2020). Practising ethically during COVID-19: social work challenges and responses. International Social Work, 63(5), 569-583.

Bay, U. (2018). Neoliberalism as an art of governance: reflecting on techniques for securing life through direct social work practice. European Journal of Social Work, 22(2), 201-211.

Becker, J. (2016). Europe's other periphery. New Left Review, II, 39-64.

Bohle, D., \& Greskovits, B. (2007a). Neoliberalism, embedded neoliberalism andneocorporatism: towards transnational capitalism in Central-Eastern Europe. West European Politics, 30(3), 443-466.

Bohle, D., \& Greskovits, B. (2007b). The state, internationalization, and capitalist diversity in Eastern Europe. Competition \& Change, 11(2), 89-115.

Cree, V. (2013). New practices of empowerment. V M. Gray, \& S. A. Webb (ur.), The new politics of social work (str. 145-158). Basingstoke: Palgrave MacMillan.

Cummins, I. (2015). Reading Wacquant: social work and advanced marginality. European Journal of Social Work, 19(2), 263-274.

Cummins, I. (2018). Poverty, inequality and social work: the impact of neo-liberalism and austerity politics on welfare provision. Policy Press Scholarship Online.

Pridobljeno 17. 12. 2020 s 10.1332/policypress/9781447334804.001.0001

Dale, G., \& Fabry, A. (2018). Neoliberalism in Eastern Europe and the former Soviet Union. V D. Cahill idr. (ur.), The Sage handbook of neoliberalism (str. 234-247). Houndmills: Sage.

Eagleton-Pierce, M. (2016). Neoliberalism: key concepts. London: Routledge.

Evans, S., Huxley, P., Gately, C., Webber, M., Mears, A., Pajak, S., Medina, J., Kendall, T., \& Katona, C. (2006). Mental health, burnout and job satisfaction among mental health social workers in England and Wales. British Journal of Psychiatry, 188(1), 75-80.

Ferguson, I., \& Lavalette, M. (2006). Globalization and global justice: towards a social work of resistance. International Social Work, 49(3), 309-318.

Florin, L., Mihai, A., Gaba, D., Ciocănel, A., Rentea, G., \& Munch, S. (2018). Romanian social workers facing the challenges of neo-liberalism, European Journal of Social Work, 22(2), 326-337.

Foucault, M. (2008). The birth of biopolitics: lectures at the College de France, 1978-79. Houndmills: Palgrave Macmillan.

Fronek, P., \& Chester, P. (2016). Moral outrage: social workers in the third space. Ethics and Social Welfare. Pridobljeno 14. 08. 2019 z doi:10.1080/17496535.2016.1151908

Garrett, P. M. (2009). Marx and 'modernization': reading Capital as social critique and inspiration for social work resistance to neoliberalization. Journal of Social Work, 9(2), 199-221.

Garrett, P. M. (2013). Social work and social theory. Bristol: Policy Press.

Garrett, P. M. (2014). Re-enchanting social work? The emerging 'spirit' of social work in an age of economic crisis. British Journal of Social Work, 44(3), 503-521.

Garrett, P. M. (2018). Welfare words: critical social work and social policy. London: Sage.

Garrett, P. M. (2019). What are we talking about when we talk about 'Neoliberalism'. European Journal of Social Work, 22(2), 188-200. 
Garrett, P. M., \& Bertotti, T. F. (2017). Social work and the politics of 'austerity': Ireland and Italy. European Journal of Social Work, 20(1), 29-41.

Gill, S. (ur.). (2012). Global crises and the crises of global leadership. Cambridge: Cambridge University Press.

Globalna izjava o etičnih načelih v socialnem delu (2018). Pridobljeno 1. 9. 2019 s https:// www.iassw-aiets.org/wp-content/uploads/2019/09/GLOBAL-SW-STATEMENT.-SLOVENE-TRANSLATION.pdf

Gray, M., Dean, M., Agllias, K., Howard, A., \& Schubert, L. (2015). Perspectives on neoliberalism for human service professionals. Social Service Review, 89(2), 368-392.

Gray, M., \& Webb, S. A. (ur.) (2013). The new politics of social work. Basingstoke: Palgrave MacMillan.

Green, D. (2007). Risk and social work practice, Australian Social Work, 60(4), 395-409.

Grover, C., \& Piggott, L. (2005). Disabled people, the reserve army of labour and welfare reform. Disability \& Society, 20(7), 705-717.

Harvey, D. (2010). A brief history of neoliberalism. Oxford: Oxford University Press.

Hedžet Tóth, C. (2012). Koliko morale prenese bogastvo. Anthropos, 225-226(1-2), 324342.

Houston, S. (2012). Reviewing the coming crisis in social work: a response to Longhofer and Floersch. Research on Social Work, 22(5), 520-522.

Hyslop, I. (2018). Neoliberalism and social work identity. European Journal of Social Work, 21(1), 20-31.

Ife, J. W. (2002). Community development: community based alternatives in an age of globalisation, 2nd ed. Frenchs Forest: Longman.

Ioakimidis, V., Santos, C. C., \& Herrero, I. M. (2014). Reconceptualizing social work in times of crisis: an examination of the cases of Greece, Spain and Portugal. International Social Work, 57(4), 285-300.

Jönsson, J. H. (2019). Servants of a 'sinking Titanic' or actors of change? Contested identities of social workers in Sweden, European Journal of Social Work, 22(2), 212-224.

Jordan, B. (2005). New labour: choice and values. Critical Social Policy, 25(4), 427-446.

Jordan, B., \& Drakeford, M. (2012). Social work and social policy under austerity. London: Palgrave Macmillan.

Karagkounis, V. (2017). Social work in Greece in the time of austerity: challenges and prospects. European Journal of Social Work, 20(5), 651-665.

Kemshall, H. (2002). Risk, social policy and welfare: introducing social policy. Buckingham: Open University Press

Kodeks etike socialnih delavk in delavcev (2021). Pridobljeno 1. 5. 2021 s: https://dsdds. splet.arnes.si/kodeks-etike/

Krašovec, P. (2016). Še enkrat o neoliberalizmu iii: psihoafektivni učinki neoliberalizma in neoliberalna subjektivnost. Andragoška spoznanja, 22(2), 67-79.

Kus, B. (2006). Neoliberalism, institutional change and the welfare state: the case of Britain and France, International Journal of Comparative Sociology, 47(6), 488-525.

Layton, L. (2010). Irrational exuberance: neoliberal subjectivity and the perversion of truth. Subjectivity, 3(3), 303-322.

Leskošek, V. (2011). Uvajanje neoliberalnega koncepta novega javnega menedžmenta v socialne dejavnosti. Socialno delo, 50(1), 43-45.

Leskošek, V. (2014). From welfare fraud to welfare as fraud. V T. Harrikari, P. L. Rauhala, \& E. Virokannas (ur.), Social change and social work: the changing societal conditions of social work in time and place (str. 49-65). Farnham and Burlington: Ashgate.

Leskošek, V. (2017). Novi oblici nadzora u socijalnom radu i socijalnoj politici: primjer Slovenije. Ljetopis Socialnog rada, 24(3), 399-414. 
Lipsky, M. (1980). Street-level bureaucracy: the dilemmas of individuals in the public service. New York: Sage.

Lorenz, W. (2005). Social work and a new social order: challenging new liberalism's erosion of solidarity. Social Work and Society, 3(1), 93-101.

Lymbery, M. (2001). Social work at the crossroads. British Journal of Social Work, 31(3), 369-384.

Morley, C., \& Macfarlane, S. (2014). Critical social work as ethical social work: using critical reflection to research students' resistance to neoliberalism. Critical and Radical Social Work, 2(3), 337-355.

Noordegraaf, M. (2016). Reconfiguring professional work changing forms of professionalism in public services. Administration \& Society, 48(7), 783-810.

Ornellas, A., Spolander, G., Engelbrecht, L. K., Sicora, A., Pervova, I., Martinez-Roman, M.-A., Law, A. K., Shajahan, P. K., Dores Guerreiro, M. des, Casanova, J. L., Garcia, M. L. T, Acar, H., Martin, L. \& Strydom, M. (2018). Mapping social work across 10 countries: structure, intervention, identity and challenges. International Social Work 62(4): 1183-1197.

Osojnik, I. (2013). Inuksuit - pet balad o neoliberalizmu za otroke. Sodobnost, 77, 4.

Parton, N., \& O’Byrne, P. (2000). Constructive social work: towards a new practice. Houndmills: Macmillan Palgrave.

Pemberton, S., Fahmy, E., Sutton, E., \& Bell, K. (2016). Navigating the stigmatised identities of poverty in austere times: resisting and responding to narratives of personal failure. Critical Social Policy, 36(1), 21-37.

Popović, D., \& Lukšič, I. (2012). Politika zidu. Teorija in praksa, 49(2), 238-300.

Pullen Sansfaçon, A. (2011). Ethics and conduct in self-directed group work: some lessons for the development of a more ethical social work practice. Ethics and Social Welfare, 5(4), 361-379.

Reisch, M. (2013). Social work education and the neo-liberal challenge: the US response to increasing global inequality. Social Work Education, 32(6), 715-733.

Rogowski, S, (2010). Social work: the rise and fall of a profession? Bristol: The Policy Press.

Rogowski, S. (2012). Social work with children and families: challenges and possibilities in the neoliberal world. British Journal of Social Work, 42(5), 921-940.

Sobočan, A. M. (2012). A gay applicant who wants to adopt a child: a case from Turkey: commentary 2. V S. Banks, \& K. Nohr (ur.), Practising social work ethics around the world: cases and commentaries (str. 143-146). London, New York: Routledge.

Sobočan, A. M. (2013). Etika v socialnem delu (doktorska disertacija). Ljubljana: A. M. Sobočan.

Sobočan, A. M. (2017). Professional identities of social workers in Slovenia. V M. Engen, M. Appel Nissen, \& L. Uggerhøj (ur.), Challenges in social work research: conflicts, barriers and possibilities in relation to social work: book of abstracts (str. 326-327). Aalborg: Aalborg University, Department of Sociology and Social Work Research. DOI:10.1080/1369 1457.2019.1640004.

Sobočan, A. M (2018). Critical incident drawn from an interview - „tell me about something that kept you awake at night?" or "tell me about an ethical dilemma?": lecture at "Professional ethical identity re-examined" at 8th European Conference for Social Work Research, Edinburgh, European Social Work Research Association, 20. 4. 2018.

Spolander, G., Engelbrecht, L., \& Pullen Sansfaçon, A. (2016). Social work and macro-economic neoliberalism: beyond the social justice rhetoric, European Journal of Social Work, 19(5), 634-649.

Spolander, G., Martin, L., Cleaver, P., \& Daly, G. (2010). Scoping a social work career framework: pilot project undertaken with five local authorities in the West Midlands. Coventry: Coventry University.

Springer, S., (2016). Fuck neoliberalism. ACME: An International Journal for Critical Geographies, 15(2), 285-292. 
Stanford (2010). Responding to the moral dilemmas of risk in social work practice. The British Journal of Social Work, 40(4), 1065-1080.

Stark, C. (2011). Neoliberalizem - izzivi za prakso in etiko socialnega dela. Socialno delo 50(3-4), 197-204.

Ule, M., \& Kurdija, S. (2013). Self-rated health among women and their assessment of the health care system. Zdravstveno varstvo, 52(2), 87-98.

Wallace, J, \& Pease, B. (2011). Neoliberalism and Australian social work: accommodation or resistance? Journal of Social Work, 11(2), 132-142.

Webb, S. A. (2006). Social work in a risk society: social and political perspectives. New York, NY: Palgrave Macmillan.

Wehbi, S., \& Turcotte, P. (2007). Social work education: neoliberalism's willing victim? Critical Social Work, 8(1), 1-9.

White, V. (2009). Quite challenges? Professional practice in modernised social work. V J. Harris, \& V. White (ur.), Modernising social work: critical considerations. Bristol: Policy Press (str. 129-144). 